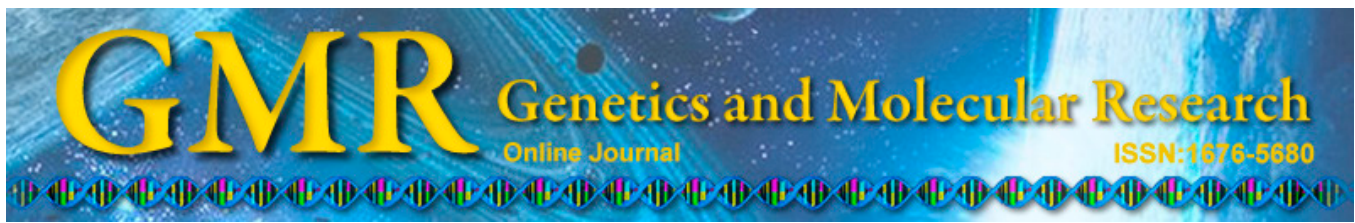

\title{
Establishment of the genomic in situ hybridization (GISH) technique for analysis in interspecific hybrids of Passiflora
}

\author{
C.A.F. Melo*, G.S. Silva* and M.M. Souza \\ Laboratório de Melhoramento de Plantas, Departamento de Ciências Biológicas, \\ Universidade Estadual de Santa Cruz, Ilhéus, BA, Brasil \\ *These authors contributed equaly to this study. \\ Corresponding author: M.M. Souza \\ E-mail: souzamagg@yahoo.com.br
}

Genet. Mol. Res. 14 (1): 2176-2188 (2015)

Received October 15, 2014

Accepted February 5, 2015

Published March 27, 2015

DOI http://dx.doi.org/10.4238/2015.March.27.4

\begin{abstract}
The genomic in situ hybridization (GISH) technique was applied to Passiflora interspecific $\mathrm{F}_{1}$ HD13-133 hybrids (Passiflora sublanceolata $\mathrm{x}$ Passiflora foetida) and HD15-101 (Passiflora gardineri x Passiflora gibertii), and the backcrossed hybrids $\left(\mathrm{BC}_{1}\right)$ HD18-106 and HD18-113 (Passiflora sublanceolata x HD13-133). GISH was performed using genomic probes prepared with the DNA from the paternal genitor, whereas the maternal DNA was used as blocking DNA and employed at various concentrations (20X, 40X, 60X, and $100 \mathrm{X})$ in relation to the probe concentration. At the same time, GISH was applied with the use of simultaneous probes from both genomes, paternal and maternal, that were detected with avidin-FITC and antidigoxigenin-rhodamine, respectively. Both methodologies allowed the distinguishing of the maternal and paternal genomes, thus confirming the hybrid nature of all the analyzed genotypes. Furthermore, the presence of recombinant chromosomes in $\mathrm{BC}_{1}$ hybrids revealed the occurrence of meiotic recombination in HD13 hybrids. This application
\end{abstract}


of the GISH technique is an important step towards genomic analyses of Passiflora hybrids: it can broaden the phylogenetic and evolutionary studies of the genus and, at the same time, contribute to breeding programs.

Key words: Cytogenetics; Blocking DNA; Plant breeding; Backcrosses; Multicolor genomic in situ hybridization; Recombinant chromosomes

\section{INTRODUCTION}

Genomic in situ hybridization (GISH) is an efficient methodology for genomic analysis that is based on the molecular cytogenetics technique of fluorescence in situ hybridization (FISH) (Schwarzacher, 2003; Wang et al., 2009). Both techniques adopt probes for hybridization and detection of the target DNA; yet, GISH uses genomic probes that are prepared by cleavage and fragmentation of genomic DNA, usually from a parent hybrid, allowing the in situ detection of the genome that is homologous to the used probe (Stace and Bailey, 1999; Schwarzacher, 2003). GISH has been widely used in genomic studies of interspecific and intergeneric hybrids, enabling both the identification of parental genomes in natural and artificial hybrids and the identification of allopolyploids through the visualization of chromosomes derived from genitor species (Guerra, 2004; Lim et al., 2004). Likewise, inferences about genomic similarities amongst closely related or related species can be performed with the application of GISH, thereby making evolutionary and phylogenetic studies possible (Lim et al., 2000b). The application of GISH in plant breeding programs has made the study of chromosomal introgression possible once it exhibits, for example, the karyotype formation of backcrossed hybrids (Jahier et al., 2009).

The major difficulty in the application of GISH is the establishment and adjustment of the technique for the species or hybrid under study. This difficulty lies in adjusting the optimal concentration of blocking DNA in such a way to enable genomic distinction without nonspecific hybridization. In GISH, the blocking DNA should preferably consist of non-target genome; thus, the blocking DNA will compete with the genomic probes, enabling specific hybridization with the target DNA such that only the genome of interest is visualized (Tang et al., 2011; Brammer et al., 2013). The use of higher concentrations of blocking DNA relative to the concentration of genomic probes is usually required in interspecific hybrids derived from phylogenetically close genitors or those with similar large genomic sequences and consequently higher homology with the probes used. Low concentrations of blocking DNA, in turn, can be used in the application of GISH amongst interspecific hybrids whose parents exhibit greater genetic distance (Anamthawat-Jónsson et al., 1990).

Passiflora is a well-known genus that includes a number of fruit (P. edulis Sims and $P$. alata Curtis) and medicinal species (P. foetida L.) of economic importance (Puricelli et al., 2003). Another explored market is that of ornamental plants, which is represented by species like Passiflora caerulea L. (Abreu et al., 2009) and Passiflora incarnata L. (Rushing, 2003), as well as interspecific hybrids that are generally the result of crossings between wild species (Abreu et al., 2009) such as Passiflora 'Sunburst' (Vanderplank, 2000). The use of passion fruits as ornamental plants is justified by the great beauty of their exotic flowers. In Europe and the United States, they are already used for decoration (Rushing, 2003). Although Brazil has great potential for the use of these passion fruits as ornamental plants and the optimum 
climatic conditions for their cultivation, this market niche remains virtually untapped in the country (Abreu et al., 2009; Santos et al., 2012).

In Brazil, Passiflora breeding programs and the production of interspecific hybrids have been conducted with the purpose of obtaining ornamental plants with unique features that are chiefly focused on the edaphoclimatic conditions. To that end, hybrids involving the species $P$. sublanceolata and $P$. foetida, which belong to the subgenus Dysosmia, supersection Stipulata, and section Dysosmia, and P. gardneri and P. gibertii, which belong to the subgenus Passiflora, supersection Stipulata, and section Granadillastrum (Ulmer and MacDougal, 2004) have already been produced. Phylogenetic studies based on plastid sequences and DNA content have revealed great genetic similarity between $P$. sublanceolata and $P$. foetida. Nonetheless, there is lower genetic similarity between $P$. gardneri and $P$. gibertii (Yotoko et al., 2011). Hybrids obtained from P. sublanceolata x P. foetida (Santos et al., 2012) and $P$. gardineri x P. gibertii (Belo, 2010) were recorded by the Passiflora Society International (http://www.passiflorasociety.org) as Passiflora 'Alva' (reference code \#120 in 2008), Passiflora 'Aninha' (\#121 in 2008), Passiflora 'Priscilla' (\#122 in 2008), Passiflora 'Gabriela' (\#170 in 2010), and Passiflora 'Bella' (\#171 in 2010). Backcrosses (BC (B) $_{1}$ have been conducted in hybrids of the progeny with the maternal parent $P$. sublanceolata (Moura et al., 2013).

Karyotypic studies involving the genus Passiflora point to the existence of chromosomal variation, suggesting that the basic number of chromosomes can be either $x_{1}=6$ or $x_{1}=12$, and $x_{2}=9$ is merely an important secondary basic number; moreover, diploid and polyploid may be the primary cytoevolutionary routes of the group (De Melo et al., 2001). In regard to the genus Passiflora, the use of molecular cytogenetic techniques has been rarely reported, whereas many of the existing studies were concerned with the distribution of the 45S and 5S ribosomal sites (De Melo and Guerra, 2003; Souza et al., 2008; Viana and Souza, 2012). The application of GISH in Passiflora has not been reported in the literature, limiting the knowledge of genomic relationships between the species and the interspecific hybrids.

This study aimed to establish the GISH technique and its application amongst interspecific Passiflora hybrids. The aim was therefore to combine cytogenetic and genomic studies of the genus, identify artificial and natural interspecific hybrids, and infer the participation of parental genomes in the karyotypic constitution of interspecific hybrids.

\section{MATERIAL AND METHODS}

\section{Plant material}

The plant material used for GISH was granted by wild passion fruit breeding programs that were directed at obtaining hybrids with ornamental potential (Table 1). The abbreviation HD refers to the progeny, whereas the following number refers to the hybrid.

\section{Slide preparation}

Root tips from cuttings were pre-treated with $0.002 \mathrm{M}$ 8-hydroxyquinoline solution at room temperature (RT) for $1 \mathrm{~h}$ and stored for $21 \mathrm{~h}$ at $8^{\circ} \mathrm{C}$ until use. Fixed roots tips were washed twice with distilled water for $5 \mathrm{~min}$, fixed in freshly prepared Carnoy fixative (3:1 
ethanol:acetic acid $[\mathrm{v} / \mathrm{v}]$; Johansen, 1940) for at least $3 \mathrm{~h}$ at RT, and stored in a freezer at $-20^{\circ} \mathrm{C}$ until use. For slide preparation, radicles were washed twice with distilled water and incubated in an enzymatic solution of $2 \%$ cellulose and $20 \%$ pectinase $(\mathrm{w} / \mathrm{v})$ for $60-80 \mathrm{~min}$ at $37^{\circ} \mathrm{C}$. Roots tips were washed with distilled water and macerated on a slide with a drop of $45 \%$ acetic acid, and a coverslip was added to the material and pressed. The coverslip was removed after freezing in liquid nitrogen, and the slide was air-dried and stored at $-20^{\circ} \mathrm{C}$ until the GISH procedure.

Table 1. Passiflora interspecific hybrids and genitors used in hybridization, type of crossing, and chromosome number $(2 n)$ of genotypes used in genomic in situ hybridization.

\begin{tabular}{llll}
\hline Hybrids & Interspecific crossing and backcrossing & Type of crossing & $2 n$ \\
\hline HD15-101 (Belo, 2010) & P. gardinerii $x$ P. gibertii & $\mathrm{F}_{1}$ & 18 \\
HD13-133 (Santos et al., 2012) & P. sublanceolata P. foetida & $\mathrm{F}_{1}$ & 22 \\
HD18-106 (Moura et al., 2013) & P. sublanceolata x HD13-133 & $\mathrm{BC}_{1}$ & 22 \\
HD18-113 (Moura et al., 2013) & P. sublanceolata x HD13-133 & $\mathrm{BC}_{1}$ & 22 \\
\hline
\end{tabular}

$\mathrm{F}_{1}=$ crossing, first generation; $\mathrm{BC}_{1}=$ backcrossing, first generation.

\section{Preparation of genomic probes and cleavage of blocking DNA}

Genomic probes were prepared using the genomic DNA of the paternal genitor from each interspecific hybrid: Passiflora gibertii for the hybrid HD15-101, P. foetida for the hybrid HD13-133, and HD13-133 for the hybrids HD18-106 and 113. Young leaves were extracted using the protocol proposed by Doyle and Doyle (1990) and quantified by electrophoresis on a 1\% agarose gel using SYBR safe (Invitrogen, United States, S33102) as a nucleic acid dye. To prepare the probes, about $20 \mu \mathrm{g}$ genomic DNA in a final volume of $200 \mu \mathrm{L}$ was cleaved using a sonicator (Qsonica, Q125) with the following settings: $40 \%$ amplitude, $2 \mathrm{~s}$ on and $2 \mathrm{~s}$ off in a total period of $5 \mathrm{~min}$ (Jauhar and Peterson, 2006). The size of cleaved fragments was determined by electrophoresis on a $2 \%$ agarose gel (Pronadisa, 8012) using a 100-bp ladder marker (New England Biolabs, United States). After genomic DNA cleavage, purification was performed by precipitating the cleaved DNA with $2 \%$ of the final volume of 3 M sodium acetate plus $200 \%$ of the final volume of cold anhydrous ethanol. The mixture was stored at $-20^{\circ} \mathrm{C}$ overnight and then centrifuged for $20 \mathrm{~min}$ at $14,000 \mathrm{rpm}$ at $20^{\circ} \mathrm{C}$ to remove the supernatant. Next, the mixture was dried at RT for at

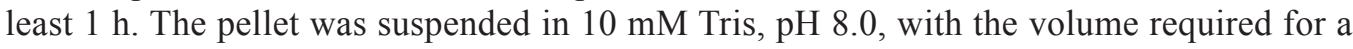
final DNA concentration of $1.1 \mu \mathrm{g} / \mu \mathrm{L}$. Probes were labeled by nick translation either with biotin-16-dUTP (Roche Diagnostics, United States, 11093070910) or digoxigenin-11-dUTP (Roche Diagnostics, United States, 11209256910) at a final concentration of $1 \mu \mathrm{g}$ of cleaved DNA as proposed by the manufacturer protocol.

Blocking DNA was prepared using about $30 \mu \mathrm{g}$ genomic DNA from the maternal genitor at a minimum final volume of $300 \mu \mathrm{L}$, which was cleaved using three methods: $(i)$ sonication with the same settings as the aforementioned preparation of genomic probes; (ii) autoclaving at $120^{\circ} \mathrm{C}$ for 5 min (Brammer et al., 2013); and (iii) incubation in a thermocycler (Eppendorf, Mastercycler) at $94^{\circ} \mathrm{C}$ for $15 \mathrm{~min}$ followed by ice for $10 \mathrm{~min}$ (Guerra, 2012). After verification of DNA cleavage on a $2 \%$ agarose gel, the cleaved DNA was purified following the same protocol that was used to prepare the probes. 


\section{GISH}

GISH application followed the protocols for in situ hybridization that were proposed by Schwarzacher and Haslop-Harrison (2000) and Souza et al. (2010) with adaptations. Slides containing the cytological preparations were oven-dried at $37^{\circ} \mathrm{C}$ for at least $1 \mathrm{~h}$ and were then subjected to treatment with $100 \mu \mathrm{g} / \mathrm{mL}$ RNase (Sigma, United States, R5125) in 2X SSC buffer [0.3 M sodium chloride (Sigma, United States, S3014) and 0.03 M sodium citrate (Sigma, United States, S5941)]; the slides were then incubated in a humid chamber for $1 \mathrm{~h}$ at $37^{\circ} \mathrm{C}$. The slides were twice immersed in $2 \mathrm{X} \mathrm{SSC}$ at RT for $5 \mathrm{~min}$ and were then treated with $50 \mu \mathrm{L} 10 \mathrm{mM}$ $\mathrm{HCl}$ for $5 \mathrm{~min}$. Next, slides were treated with $50 \mu \mathrm{L}$ pepsin (Sigma, United States, P6887) [10 $\mathrm{mg} / \mathrm{mL}$ pepsin and $10 \mathrm{mM} \mathrm{HCl}(1: 100 \mathrm{v} / \mathrm{v})]$. The following washing stages were carried out in a stirring platform at $120 \mathrm{rpm}$ (Biomixer, Mos-1). The slides were rinsed twice in 2X SSC at RT for $5 \mathrm{~min}$, immersed in 4\% paraformaldehyde for $10 \mathrm{~min}$ at RT, and washed twice in 2X SSC for $5 \mathrm{~min}$. Cytological preparations were dehydrated in two steps: in $70 \%$ ethanol and in $96 \%$ ethanol, each for $5 \mathrm{~min}$. After the slides were dried for $30 \mathrm{~min}$ at RT, the hybridization mixture was added at a final volume of 50\% formamide (Sigma, United States, P9037), 10\% dextran sulfate (Sigma, United States, 42867), 2X SSC, 0.13\% sodium dodecyl sulfate (Bioagency, 161$0301 \mathrm{~N}$ ), and $33 \mathrm{ng}$ genomic probe. Two tests regarding the blocking DNA were carried out: $(i)$ using four concentrations of blocking DNA relative to the genomic probe concentration (33 ng): (a) 20X (660 ng); (b) 40X (1.36 $\mu$ g) (only with the hybrid HD15-101), (c) 60X (1.98 $\mu \mathrm{g}$ ) and (d) $100 \mathrm{X}(3.3 \mu \mathrm{g})$; and (ii) preparations without blocking DNA and using probes of both maternal and paternal genitors (only with hybrids HD15-101 and HD18-113).

The hybridization mixture was heated to $75^{\circ} \mathrm{C}$ for $10 \mathrm{~min}$ in a thermocycler and immediately transferred to ice for at least $5 \mathrm{~min}$. Cytological preparations containing the hybridization mixture were denatured in a thermocycler containing a slide adapter (Techne, T-412a) at $75^{\circ} \mathrm{C}$ for $10 \mathrm{~min}$ and then were incubated overnight in a humidified chamber at $37^{\circ} \mathrm{C}$. After hybridization, the slides were soaked in $2 \mathrm{X}$ SSC at RT for $5 \mathrm{~min}$ to remove coverslips and then were subjected to a post-hybridization bath at $42^{\circ} \mathrm{C}$ in a Dubnoff bath (Quimis, 9226ML). The bath consisted of two 5-min immersions in 2X SSC, another two 5-min immersions in $0.1 \mathrm{X}$ SSC, and two 5-min immersions in 2X SSC. The slides were dipped in a $4 \mathrm{X}$ SSC and $0.02 \%$ Tween 20 (Sigma, United States, P7949) solution at RT for 5 min and were treated with $5 \%$ bovine serum albumin (BSA), fraction V (Sigma, United States, A3059). Biotin-labeled genomic probes were detected with $0.7 \mu \mathrm{L}$ avidin-fluorescein isothiocyanate (FITC) (Vector, United Kingdom, SA-5001) plus $19.3 \mu \mathrm{L}$ 5\% BSA per slide. For the second test (ii), biotinlabeled and digoxigenin-labeled genomic probes were detected with the addition of $0.7 \mu \mathrm{L}$ avidin-FITC and $0.7 \mu \mathrm{L}$ anti-digoxigenin-rhodamine (Roche, United States, 11207750910) plus $18.6 \mu \mathrm{L} 5 \%$ BSA per slide. Slides containing the antibodies for detection were incubated in a humid chamber for $1 \mathrm{~h}$ at $37^{\circ} \mathrm{C}$. To remove excess antibodies, three 5-min baths were carried out in $4 \mathrm{X} \mathrm{SSC}$ and $0.2 \%$ Tween 20 at RT. Slides were briefly rinsed with $2 \mathrm{X} \mathrm{SSC}$, and cytological preparations were simultaneously counterstained and mounted with DAPI medium/Vectashield ${ }^{\circledR}(\mathrm{H}-1200)$. The slides were stored for up to 3 days at $6^{\circ}-8^{\circ} \mathrm{C}$ until analysis.

\section{Photo-documentation and analysis}

Slides were examined using an Olympus BX41 epifluorescence microscope fitted with a DP25 photo-documentation system. To visualize FITC and tetramethylrhodamine iso- 
thiocyanate (TRITC) fluorochromes, the filters U-MWB (450-480 nm excitation, $500 \mathrm{~nm}$ dichroic cutoff, emission $>515 \mathrm{~nm}$ ) and U-MWG (510-550 nm excitation, $570 \mathrm{~nm}$ dichroic cutoff, emission $>590 \mathrm{~nm}$ ) were used, respectively, whereas the counterstaining with DAPI was visualized using the U-MWU filter (330-385 nm excitation, $400 \mathrm{~nm}$ dichroic cutoff, emission $>420 \mathrm{~nm}$ ). Photo-documentation was performed by the DP25 5 Megapixel system with the DP2-BSW software (Olympus). Two image-capture methods were tested: (i) high exposure (> $2 \mathrm{~s})$ with ISO 50 and (ii) low exposure $(<250 \mathrm{~ms})$ with ISO 200. Analysis of results, preparation of figures, and FITC/DAPI overlays (superposition of layers using 75\% opacity of FITC) were carried out using the Photoshop SC5 software (open source).

\section{RESULTS}

To prepare the blocking DNA for GISH, the genomic DNA of the paternal genitors, P. gardneri and P. sublanceolata, were cleaved using three different methods that aimed to obtain fragments between 100 and $800 \mathrm{bp}$ (Figure 1). The use of a sonicator in the cleavage of genomic DNA resulted in the best cleavage profile after gel electrophoresis on $2 \%$ agarose. Sonication resulted in the cleavage of fragments greater than $200 \mathrm{bp}$ but with a prevalence of fragments between 200 and $1000 \mathrm{bp}$. The use of an autoclave in the preparation of blocking DNA only cleaved genomic DNA to fragments smaller than $200 \mathrm{bp}$, and thermal shock produced high concentrations of fragments greater than $1200 \mathrm{bp}$. Therefore, blocking DNA for GISH was cleaved by sonication.

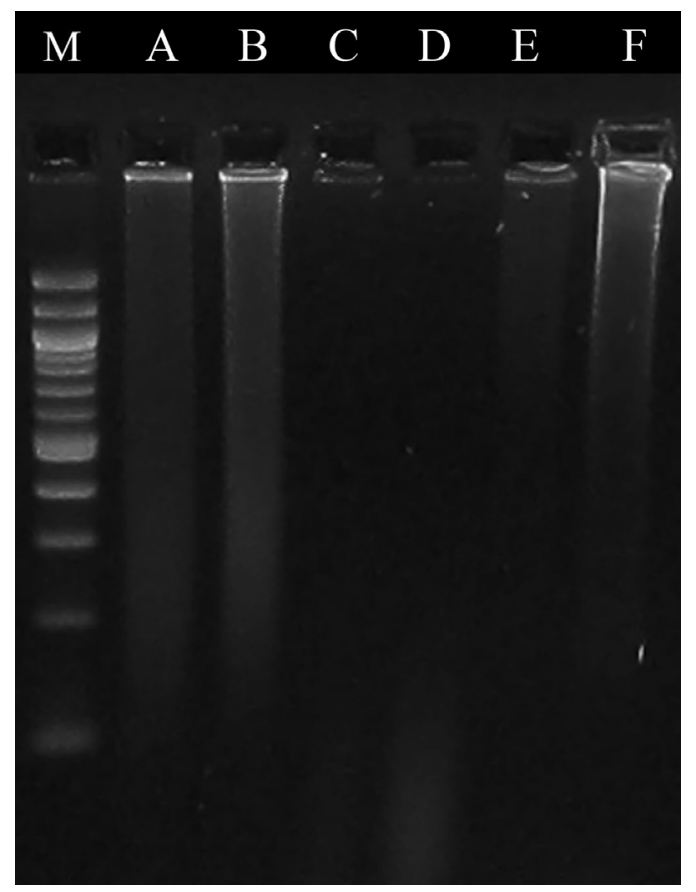

Figure 1. Agarose gel electrophoresis of $1.1 \mu \mathrm{g}$ blocking DNA used for genomic in situ hybridization (GISH) in Passiflora. Lane $M=100$-bp ladder; lanes $A$ and $B=$ cleavage using a sonicator; lanes $C$ and $D=$ cleavage using autoclave; lanes $E$ and $F$ = cleavage using thermal shock; A, C, and E, P. sublanceolata; B, D, and F, P. gardneri. 
GISH of interspecific hybrids $\mathrm{F}_{1}$ HD15-101 $(2 n=18)$, HD13-133 $(2 n=22)$, and $\mathrm{BC}_{1}$ HD18-106 $(2 n=22)$ using blocking DNA with a concentration 20X higher than that of the genomic probes of paternal genitors did not exhibit good results because of cross-hybridization, making it impossible to safely distinguish the target genome (Figure 2A-C). In analysis of the interspecific hybrid HD15-101, the use of 40X blocking DNA allowed the visualization of hybridized chromosomes, giving the target genome the typical green fluorescence (FITC); nevertheless, the strong occurrence of cross-hybridization with non-target genomes revealed the need of using blocking DNA (Figure 2D).
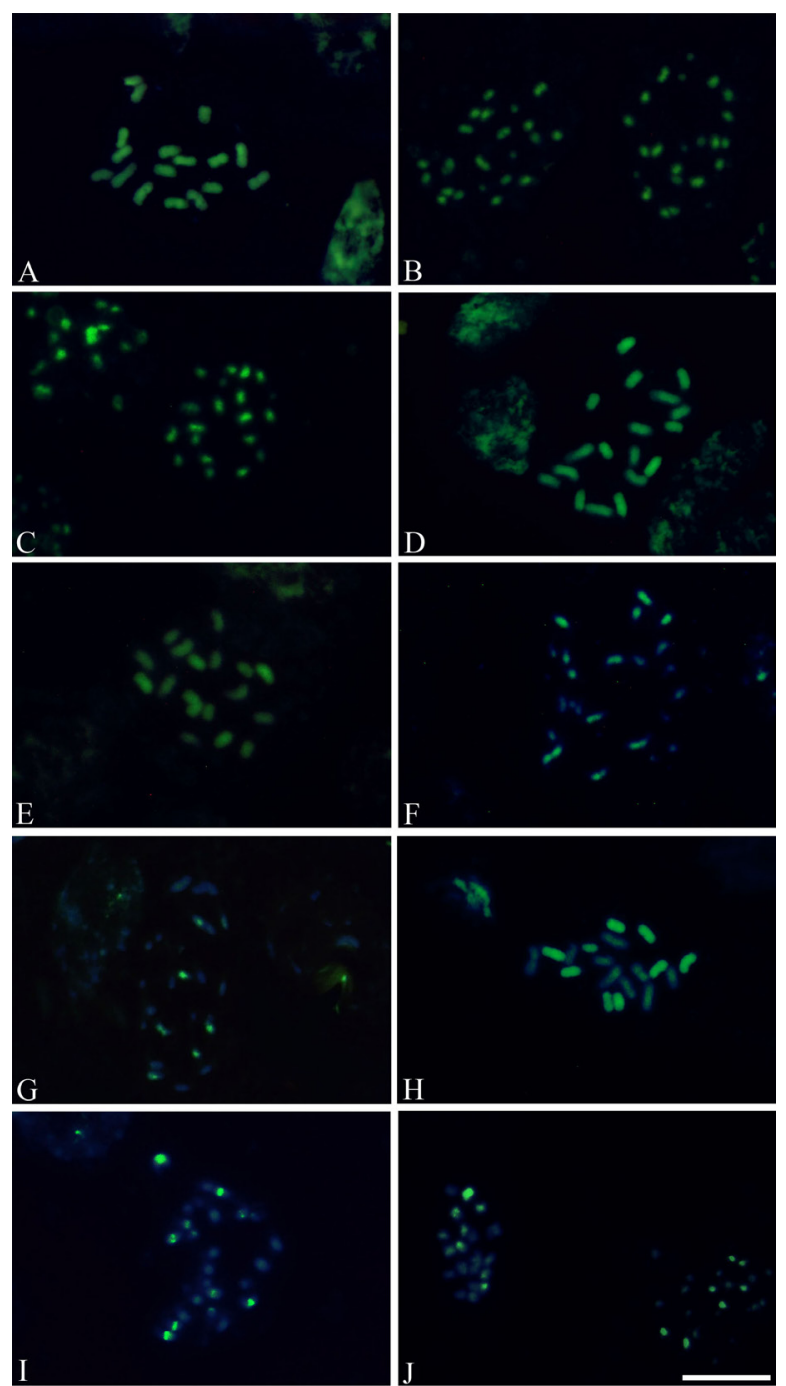

Figure 2. Application of GISH in interspecific and backcrossed hybrids of Passiflora. A, D, E, and $\mathbf{H}$, interspecific hybrid $\mathrm{F}_{1}$ HD15-101 with the following blocking DNA concentrations: 20X, 40X, 60X, and 100X, respectively; B, $\mathbf{F}$, and I, interspecific hybrid HD13-133 with $20 \mathrm{X}, 60 \mathrm{X}$, and 100X blocking DNA, respectively; $\mathbf{C}$, G, and $\mathbf{J}, \mathrm{BC}_{1}$ HD18-106 with 20X, 60X, and 100X blocking DNA, respectively. Bar $=10 \mu \mathrm{m}$. 
GISH using 60X blocking revealed the involvement of nine chromosomes of $P$. giber$t i i$, which is the target genome, in the genomic constitution of HD15-101 (Figure 2E). Hence, the use of 60X blocking DNA is an option to distinguish hybrid genomes in the hybrids of the progeny HD15. Yet, chromosomes from the maternal genitor ( $P$. gardneri) in HD15-101 also showed hybridization signals. The application of GISH with 60X blocking DNA in HD13-133 and HD18-106 showed specific hybridization with some chromosomes of the target genome, thus enabling the visualization of chromosomes derived from the paternal genitors (Figure $2 \mathrm{~F}$ and G). On the other hand, chromosomes from the non-target maternal genome showed crosshybridization (especially the larger chromosomes), leading us to question whether translocations could exist in the progeny HD18, especially when high exposures ( $>2 \mathrm{~s})$ or high ISO (200) are used in photo-documentation.

The use of 100X blocking DNA revealed the presence of nine strongly hybridized chromosomes in the hybrid HD15-101, representing the genome of $P$. gibertii in the genomic constitution of the hybrid (Figure 2H). In HD15-101, the nine chromosomes of the maternal genitor ( $P$. gardneri), whose DNA was used as blocking DNA, showed no hybridization signals. This demonstrated that the use of $100 \mathrm{X}$ blocking DNA makes possible a clear distinction of the genitor genomes in HD15-101.

In HD13-133, the use of 100X blocking DNA resulted in specific hybridization of the target genome, as 12 chromosomes were partially or fully hybridized, allowing the safe distinction of both genomes in the constitution (Figure 2I). The use of 100X blocking DNA in the hybrid HD18-106 indicated the existence of three fully hybridized chromosomes and another five chromosomes with hybridization signals on the short or long chromosome arms. This revealed the presence of chromosomes with recombination between the maternal $(P$. sublanceolata) and the paternal genomes ( $P$. foetida) in HD18-106 (Figure 2J).

The application of GISH using probes from both genitors simultaneously and without the addition of blocking DNA made the distinction of the genitor genomes possible. In the prometaphases and metaphases of the hybrid HD15-101, nine hybridized chromosomes with genome probes of the paternal genitor were observed, and they were detected with avidinFITC (green) and visualized with a U-MWB filter. The same filter that was used to detect FITC signals excited TRITC fluorescence (red) and revealed nine hybridized chromosomes with the probes of the maternal genitor, which, due to the mixing of FITC-TRITC signals, showed an opaque fluorescence (Figure 3A and B). The use of a U-MWG filter to detect the maternal genomic probes (TRITC signals) in HD15-101 exhibited nine strongly hybridized chromosomes (Figure 3C).

In the hybrid HD13-133, the application of GISH with the use genomic probes from both parents simultaneously and without the addition of blocking DNA revealed 12 chromosomes with clear signals of paternal genome probe hybridization, which were detected with avidin-FITC/U-MWB, and another 10 chromosomes that were hybridized with probes of the maternal genome, which were detected with anti-digoxigenin-rhodamine and visualized using the same filter, revealing an opaque yellow staining as a result of the mixing of the FITC and TRITC signals (Figure 3D). In HD18-113, in turn, the application of GISH with the concomitant use of probes without blocking DNA revealed nine chromosomes that strongly hybridized with the paternal genomic probes, which were detected with a U-MWB filter for FITC fluorescence. One chromosome only exhibited a hybridization signal on one chromosome arm, denoting recombination (Figure 3E). With the aid of a U-MWB filter, chromosomes derived from the maternal genome in HD18-113 showed an opaque yellow fluorescence (Figure 3E). 
The use of a U-MWG filter to detect TRITC fluorescence did not allow the indisputable distinction of maternal and paternal genomes in HD13-133 and HD18-113 (Figure 3F).
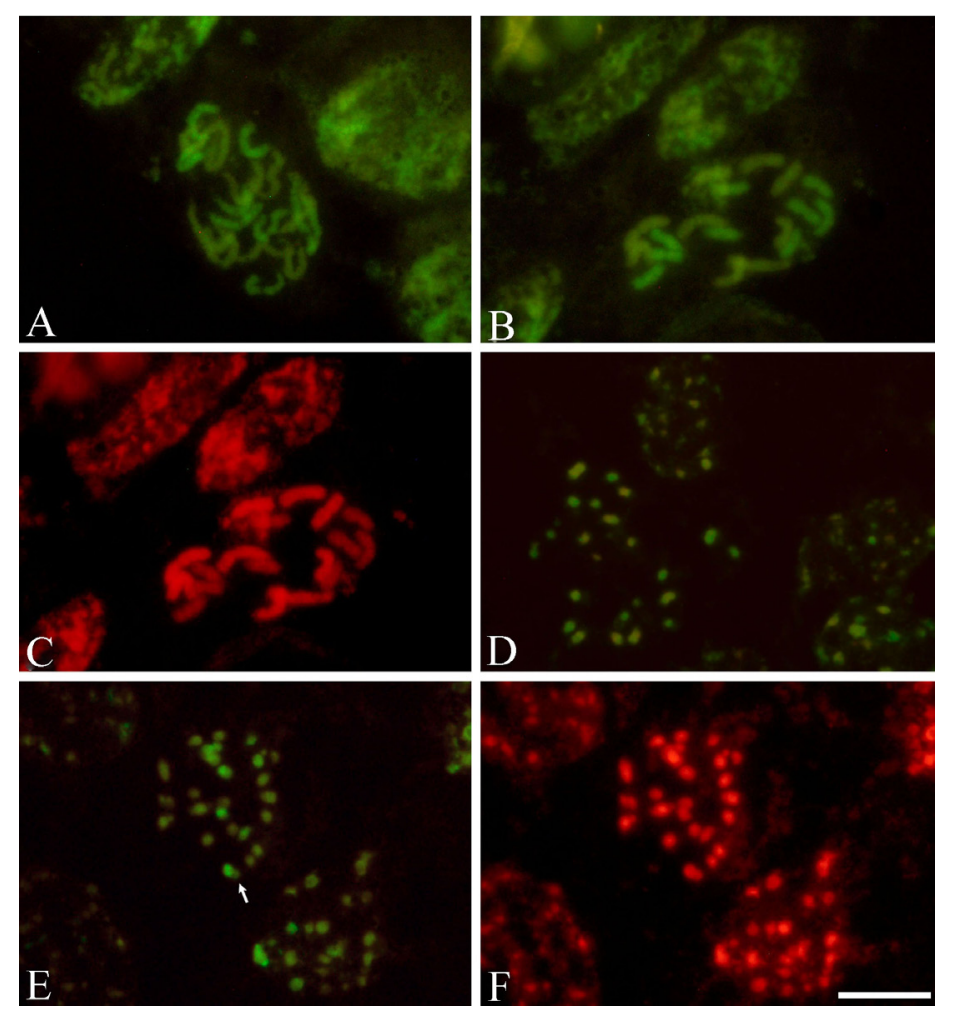

Figure 3. Two probes for GISH without blocking DNA in Passiflora. Paternal and maternal genomic probes were detected by avidin-fluorescein isothiocyanate (FITC, green) and anti-digoxigenin-rhodamine (red), respectively. A and $\mathbf{B}$, prometaphase and metaphase chromosomes of the hybrid $\mathrm{F}_{1}$ HD15-101 detected by a U-MWB filter showing nine chromosomes from each maternal (yellow) and paternal (green) genomes; $\mathbf{C}$, maternal chromosomes of $\mathrm{F}_{1}$ HD15-101 detected by anti-digoxigenin-rhodamine (red); D, metaphase chromosomes of the hybrid $\mathrm{F}_{1}$ HD13-133 showing chromosomes from the maternal (yellow) and paternal (green) genomes; E, BC 1 HD18-113 detected by avidin-FITC (green) for paternal chromosomes and yellow for maternal chromosomes; F, BC 1 HD18-113 detected by anti-digoxigenin-rhodamine (red) where no genomic distinction can be made. Arrow in $\mathrm{E}$ indicates recombinant chromosomes in $\mathrm{BC}_{1}$. Bar $=10 \mu \mathrm{m}$.

\section{DISCUSSION}

In this study, the GISH technique was first applied in Passiflora to distinguish the parental genomes in interspecific ornamental hybrids. Besides confirming the hybrid character, GISH allowed the observation of recombinant chromosomes in backcrossed hybrids $\left(\mathrm{BC}_{1}\right)$. The use of GISH to identify natural hybrids, to confirm artificial hybridization (Marasek et al., 2004; Contreras et al., 2012), and to identify recombined chromosomes in backcrossed progenies $\mathrm{BC}_{1}$ and $\mathrm{BC}_{2}$ (Karlov et al., 1999; Lim et al., 2000b; Marasek-Ciolakowska et al., 2012) has been widely reported for different plant groups. Hybrids BC $_{1}$ HD18-106 and HD18-113 showed different numbers of recombinant chromosomes, denoting variation in the meiotic 
recombination amongst homeologous chromosomes in HD13 hybrids. A wide variation in the quantity of recombinant chromosomes is commonly reported in the hybrids $\mathrm{BC}_{1}$ and $\mathrm{BC}_{2}$ (Marasek-Ciolakowska et al., 2012). GISH is also used in the analysis of recombination in meiotic chromosomes (Lim et al., 2000a).

Establishing the GISH technique requires the adjustment and optimization of several factors, namely $(i)$ the size of DNA fragments in the preparation of probes and/or as blocking DNA, (ii) use of probes from both genitors, (iii) variations in the levels of stringency used in post-hybridization baths, and (iv) variations in the concentrations of probes and blocking DNA added to the hybridization mix (Schwarzacher and Haslop-Harrison, 2000; Czernicka et al., 2010).

In order to perform GISH in Passiflora hybrids, the sonication of genomic DNA was the most efficient cleavage method amongst the methods tested. Sonication was seen to provide the best profile after electrophoresis, with a predominance of fragments ranging from 200 to $1000 \mathrm{bp}$, i.e., more suitable for the preparation of genomic probes and labeling more efficient by nick translation (Schwarzacher and Haslop-Harrison, 2000). Genomic DNA fragments ranging between 50-300 bp are commonly used to block the hybridization of repetitive DNA sequences present in the probe. Depending on the stringency used in hybridization, those fragments also block similar sequences from both genitor species of an interspecific hybrids (Wilkinson, 1998; Schwarzacher and Haslop-Harrison, 2000). In turn, larger fragments, between 1 and $10 \mathrm{~kb}$, were used for the preparation of genomic probes directed to some genera, such as Lilium (Lim et al., 2004).

In this study, the DNA that was cleaved by sonication was both employed in the preparation of genomic probes and used as blocking DNA. Some methods proposed for GISH apply two different methods for the cleavage of genomic DNA: one directed to the cleavage of DNA for probes and another for blocking DNA, wherein sonication is generally used to cleave the DNA for the probe, and the autoclave is used to cleave the blocking DNA (Jauhar and Peterson, 2006; Marasek-Ciolakowska et al., 2012). Various reports on the use of autoclaving as a sole DNA cleavage method either in the preparation of probes or in the direct use as blocking DNA suggest that autoclaving is an efficient method of DNA fragmentation (Lim et al., 2004; Brammer et al., 2013). Nevertheless, as revealed in this study, small fragments $(<100 \mathrm{bp})$ were obtained with the simple use of an autoclave for $5 \mathrm{~min}$ at $120^{\circ} \mathrm{C}$, showing the need to adjust the DNA fragmentation method. DNA cleavage by autoclaving can be influenced by parameters such as temperature, fragmentation time, final volume, and autoclave model; there is a large variation in fragment sizes relative to the time of fragmentation (Jauhar and Peterson, 2006; Marasek-Ciolakowska et al., 2012; Brammer et al., 2013).

The best results were obtained when the concentrations of the probe and blocking DNA were $33.3 \mathrm{ng}$ and $33.3 \mu \mathrm{g}$, respectively, per slide, revealing the use of $100 \mathrm{X}$ blocking DNA compared to the probe. Deviation from this optimum point (100X concentrated), both relative to the concentration of the probe and the proportion (probe:blocking DNA), influenced the resolution of results (Brammer et al., 2013). Using high concentrations of blocking DNA in Passiflora hybrids reveals a strong tendency towards cross-hybridization, which is usually caused by the similarities between repetitive DNA sequences that are common in the maternal and paternal genomes (Marasek et al., 2004). The addition of blocking DNA at concentrations higher than that of the probe is the most varied parameter amongst the several protocols that were proposed for GISH; it was adjusted as a function of the evolutionary and taxonomic levels of the genitor species. However, the greater the phylogenetic and genomic 
proximity between the genitors, the higher are the concentrations of blocking DNA in order to reduce cross-hybridization (Schwarzacher and Haslop-Harrison, 2000).

The simultaneous addition of more than one probe to the hybridization mix is called the multicolor GISH (mGISH) technique (Li et al., 2001a,b; Xiong et al., 2006). Even at low stringency levels, mGISH showed good resolution in the karyotypic characterization of species of complex genomic constitution, such as allotetraploids (Li et al., 2001a,b). Cytological observations demonstrated that the simultaneous use of probes from both genitors of Passiflo$r a$ hybrids enabled the visualization of both genomes among the hybrids that were analyzed in this study. The simultaneous use of two probes, one from each genitor, is not indicated in cases of genetically close genitors because high levels of cross-hybridization can lead to a mixture of both fluorescences. In these cases, the use of blocking DNA along with the two probes may be necessary (Schwarzacher and Haslop-Harrison, 2000).

Likewise, the use of only one filter (Olympus U-MWB) specific for FITC (green) detection made possible the visualization of chromosomes preferably hybridized by the probes detected by anti-digoxigenin-rhodamine, making clear the mixing of FITC-TRITC signals (opaque yellow). The ability of specific filters to detect FITC fluorescence and at the same time to excite red fluorescence (TRITC) was observed in Passiflora, where strong TRITC hybridization sites are seen in conjunction with FITC hybridization sites, and TRITC fluorescence becomes yellow (De Melo and Guerra, 2003). The inability of a U-MWG filter to detect the maternal genome using anti-digoxigenin-rhodamine (strong hybridization signal), as well as to visualize hybridization signals in hybrids HD13-133 and HD18-113, can be ascribed to the small size of chromosomes in conjunction with the genomic similarity between the genitors $P$. sublanceolata and $P$. foetida (Yotoko et al., 2011). On the other hand, the U-MWG filter made possible a clear distinction between the maternal and paternal genomes in HD15-101; this fact is related to the larger chromosome size and a greater genomic distance between the genitors. The application of GISH in hybrids or species with small chromosomes may lead to a loss of resolution in hybridizations, and the occurrence of hybridization sites might be limited to pericentromeric or heterochromatic regions (Czernicka et al., 2010; Marasek-Ciolakowska et al., 2012).

The application of GISH in Passiflora showed unambiguous and reliable results relative to the distinction of genitor genomes in hybrids. The results obtained by both methodologies, GISH using blocking DNA and GISH using two probes simultaneously, enlighten the research decisions about the most suitable technique for germplasm in analysis. Nonetheless, both techniques showed positive results even with small chromosomes (1 to $2.5 \mu \mathrm{m}$ ) when it came to the hybrids HD13-133, HD18-106, and HD18-113. GISH allowed the observation of recombination amongst hybrids derived from backcrosses $\left(\mathrm{BC}_{1}\right)$, which broadens the possibilities of genomic analysis in natural and artificial hybrids. Hence, the application of GISH in Passiflora enables the recognition of potential genitor species, and it can be used for cytogenetic analysis and detection of morphological markers in breeding programs.

\section{ACKNOWLEDGMENTS}

Research supported by Universidade Estadual de Santa Cruz and Fundação de Amparo à Pesquisa do Estado da Bahia. Coordenação de Aperfeiçoamento de Pessoal de Nível Superior granted scholarships to the first and second authors, and Conselho Nacional de Desenvolvimento Científico e Tecnológico awarded a scholarship to the last author. 


\section{REFERENCES}

Abreu PP, Souza MM, Santos EA and Pires MV (2009). Passion flower hybrids and their use in the ornamental plant market: perspectives for sustainable development with emphasis on Brazil. Euphytica 166: 307-315.

Anamthawat-Jónsson K, Schwarzacher T, Leitch AR, Bennett MD, et al. (1990). Discrimination between closely related Triticeae species using genomic DNA as a probe. Theor. Appl. Genet. 79: 721-728.

Belo GO (2010). Análises Morfológicas e Genéticas em Progênie Híbrida F1 do Cruzamento Passiflora Gardneri MAST x Passiflora gibertii N.E. BROW. Master's thesis. Universidade Estadual de Santa Cruz, Ilhéus.

Brammer SP, Vasconcelos SS, Poersch LB and Oliveira AR (2013). Genomic in Situ Hybridization in Triticeae: A Methodological Approach. In: Plant breeding from laboratories to fields, Rijeka, 3-22.

Contreras RN, Ruter JM, Conner J, Zeng Y, et al. (2012). Confirmation of hybridity using GISH and determination of $18 \mathrm{~S}$ rDNA copy number using FISH in interspecific F(1) hybrids of Tecoma (Bignoniaceae). Genome 55: 437-445.

Czernicka M, Mścichowska A, Klein M, Muras P, et al. (2010). Paternity determination of interspecific rhododendron hybrids by genomic in situ hybridization (GISH). Genome 53: 277-284.

De Melo NF and Guerra M (2003). Variability of the 5S and 45S rDNA sites in Passiflora L. species with distinct base chromosome numbers. Ann. Bot. 92: 309-316.

De Melo NF, Cervi AC and Guerra M (2001). Karyology and cytotaxonomy of the genus Passiflora L. (Passifloraceae). Plant Syst. Evol. 226: 69-84.

Doyle JJ and Doyle JL (1990). Isolation of plant DNA from fresh tissue. Focus 12: 13-15.

Guerra M (2004). Hybridization in Situ: Princípios Básicos. In: FISH: Fonceitos e Aplicações na Citogenética (Guerra M, ed.). Sociedade Brasileira de Genética, Ribeirão Preto, 1-32.

Guerra M (2012). Citogenética Molecular: Protocolos Comentados. Sociedade Brasileira de Genética, Ribeirão Preto.

Jahier J, Chain F, Barloy D and Tanguy AM (2009). Effect of combining two genes for partial resistance to Barley yellow dwarf virus-PAV (BYDV-PAV) derived from Thinopyrum intermedium in wheat. Plant Pathol. 58: 807-814.

Jauhar PP and Peterson TS (2006). Cytological analyses of hybrids and derivatives of hybrids between durum wheat and Thinopyrum bessarabicum, using multicolor fluorescent GISH. Plant Breed. 125: 19-26.

Johansen DA (1940). Plant Microtechnique. McGraw Hill, New York.

Karlov GI, Khrustaleva LI, Lim KB and Van Tuyl JM (1999). Homoeologous recombination in 2n-gametes producing interspecific hybrids of Lilium (Liliaceae) studied by genomic in situ hybridization (GISH). Genome 42: 681-686.

Li CB, Zhang DM, Ge S and Lu BR (2001a). Identification of genome constitution of Oryza malampuzhaensis, O. minuta, and O. punctata by multicolor genomic in situ hybridization. Theor. Appl. Genet. 103: 204-211.

Li CB, Zhang DM, Ge S and Lu BR (2001b). Differentiation and inter-genomic relationships among C, E and D genomes in the Oryza officinalis complex (Poaceae) as revealed by multicolor genomic in situ hybridization. Theor. Appl. Genet. 103: 197-203.

Lim KB, Chung JD, van Kronenburg BC, Ramanna MS, et al. (2000a). Introgression of Lilium rubellum Baker chromosomes into L. longiflorum Thunb.: a genome painting study of the $\mathrm{F} 1$ hybrid, $\mathrm{BC} 1$ and $\mathrm{BC} 2$ progenies. Chromosome Res. 8: 119-125.

Lim KY, Matyasek R, Lichtenstein CP and Leitch AR (2000b). Molecular cytogenetic analyses and phylogenetic studies in the Nicotiana section Tomentosae. Chromosoma 109: 245-258.

Lim KY, Matyasek R, Kovarik A and Leitch AR (2004). Genome evolution in allotetraploid Nicotiana. Biol. J. Linn. Soc. 82: $599-606$

Marasek A, Hasterok R, Wiejacha K and Orlikowska T (2004). Determination by GISH and FISH of hybrid status in Lilium. Hereditas 140: 1-7.

Marasek-Ciolakowska A, He H, Bijman P and Ramanna MS (2012). Assessment of intergenomic recombination through GISH analysis of F1, BC1 and BC2 progenies of Tulipa gesneriana and T. fosteriana. Plant Syst. Evol. 298: 887-899.

Moura AS, Melo CAF and Souza MM (2013). Caracterização Morfológica de Progênies Híbridas Interespecíficas Retrocruzadas de Passifloras. $65^{\text {a }}$ Reunião anual da sociedade brasileira para o progresso da ciência. Passiflora Society. Available at: [http://www.passiflorasociety.org/] Accessed May 5, 2013, Recife.

Puricelli L, Dell'Aica I, Sartor L, Garbisa S, et al. (2003). Preliminary evaluation of inhibition of matrix-metalloprotease MMP-2 and MMP-9 by Passiflora edulis and P. foetida aqueous extracts. Fitoterapia 74: 302-304.

Rushing F (2003). Tough Plants for Southern Gardens: Low Care, no Care, Tried and True Winners. Cool Springs Press, Nashville.

Santos EA, Souza MM, Abreu PP and Conceição LDHCS (2012). Confirmation and characterization of interspecific hybrids of Passiflora L. (Passifloraceae) for ornamental use. Euphytica 184: 389-399.

Schwarzacher T (2003). DNA, chromosomes, and in situ hybridization. Genome 46: 953-962. 
Schwarzacher T and Haslop-Harrison P (2000). Practical in Situ Hybridization. Springer-Verlag Inc., New York.

Souza MM, Pereira TNS and Vieira MLC (2008). Cytogenetic studies in some species of Passiflora L. (Passifloraceae): a review emphasizing Brazilian species. Braz. Arch. Biol. Technol. 51: 247-258.

Souza MM, Urdampilleta JD and Forni-Martins ER (2010). Improvements in cytological preparations for fluorescent in situ hybridization in Passiflora. Genet. Mol. Res. 9: 2148-2155.

Stace CA and Bailey JP (1999). The Value of Genomic in situ Hybridization (GISH) in Plant Taxonomic and Evolutionary Studies. In: Molecular Systematics and Plant Evolution (Hollingsworth PM, Bateman RM and Gornall RJ, eds.). CRC Press, London, 199-210.

Tang F, Wang H, Chen S and Chen F (2011). Intergeneric hybridization between Dendranthema nankingense and Tanacetum vulgare. Sci. Hort. 132: 1-6.

Ulmer T and MacDougal JM (2004). Passiflora-Passionflowers of the World. Timber Press, Portland.

Vanderplank J (2000). Passion Flowers. 3rd edn. MIT Press, Cambridge.

Viana AJ and Souza MM (2012). Comparative cytogenetics between the species Passiflora edulis and Passiflora cacaoensis. Plant Biol (Stuttg).

Wang Y, Zhi H, Li W and Li H (2009). A novel genome of C and the first autotetraploid species in the Setaria genus identified by genomic in situ hybridization. Genet. Resour. Crop Evol. 56: 843-850.

Wilkinson DG (1998). In Situ Hybridization-a Practical Approach. Oxford University Press, Oxford.

Xiong ZY, Tan GX, He GY, He GC, et al. (2006). Cytogenetic comparisons between A and G genomes in Oryza using genomic in situ hybridization. Cell Res. 16: 260-266.

Yotoko KSC, Dornelas MC, Togni PD and Fonseca TC (2011). Does variation in genome sizes reflect adaptive or neutral processes? New clues from Passiflora. PLoS One 6: e18212. 